UDK 658.3.07

DOI: $10.18524 / 2413-9998 / 2019.3(43) .183653$

\author{
Horbachenko Stanislav, \\ $\mathrm{PhD}$ in Economics, \\ Associate Professor, \\ Department of Management and Innovation \\ of Odessa I. I. Mechnikov National University \\ 24/26 Frantsuzkyi bulvar, Odessa, 65058, Ukraine, \\ e-mail: stas_gorbachenko@ukr.net \\ Kharlamova Victoriia, \\ student of the second year of magistracy \\ specialties of Foreign Economic Relations \\ Department of Management and Innovation \\ of Odessa I. I. Mechnikov National University \\ 24/26 Frantsuzkyi bulvar, Odessa, 65058, Ukraine, \\ e-mail: kharlamova7.16@gmail.com
}

\title{
MANAGEMENT TEAMS
}

The peculiarities of the creation of management teams in Ukraine at the present stage of the information society to solve the tasks are investigated. As technology evolves, so does the responsibility of people for their work, and so for the sake of simplification and productivity of the team began to appear in large organizations groups of people who share responsibilities. The method of solving problems with the help of "team thinking" significantly improves the work of the organization, such indicators as the number of ideas, creative approach to solving problems and teaming. The actual problems of the formation of separate direction in management are analyzed and ways of effective functioning of management teams are suggested. The article examines the modern experience of approaches to team management.

Keywords: management teams; management team; personnel management; professional activity of specialists; team building; management innovations; maritime complex; team thinking.

Introduction. The problem of team thinking is not very noticeable at first glance without a thorough consideration of its aspects.

By studying the exceptionally prevalent features of this information society product, one can then come across some negative aspects of this theory that can slow down the work of a team in a large company.

To begin with, you need to deal with the positive features of team thinking. 
First, it is a creative approach to solving the various problems that arise in the company over time.

Secondly, it is some different ideas for solving certain problems. Because this is a team that is practically the only mechanism, the ideas for solving the problems will be about the same as the number of people included in this team.

Thirdly, it is, of course, a grouping of the team, which may not be very friendly at first.

Now, it is important to consider these positive qualities, on the other hand, revealing, accordingly, the disadvantages of this theory.

The approach to solving problems can be slowed down by different opinions in the team and the inability to reach a common opinion. This will create another problem beyond the original one, which has led to a conflict of opinion. These are two problems that will have to be solved quickly enough due to the force majeure obtained.

Similarly, the team may have good employees who do not want to contact other people in the company. Because of their good work, it will not be possible to downplay a position, which, of course, will not be a good influence on team thinking because this approach implies the creation of small groups in the company to solve the tasks. The one-size-fits-all solution is not supported in an information society that resembles democracy, which in turn is not a good form of government.

The relevance of the article is intended to understand more deeply these problems and find solutions, to make a comparative analysis of different approaches to management teams, as well as to understand the possibilities of application on the maritime complex.

The degree of investigation of the problem. Issues of management teams are devoted to the work of such scientists as Versta Y. A., Gellert M., Novak K., Newstrom J. V., Davis K., Bazarov T. Yu., Zinkevich-Evstigneeva T. D., Frolov D. F., Grabenko T. M., Yakokka L., Chitra O. V., Borshch V. I., Kalinets K. S., Olenich A. V., Shatska Z. Y., Thompson L., Martsinkovskaya O. B., Pomaz O. M., Shulzhenko I. V., Lyubchuk O. K. etc. In recent years, there has been a great deal of research in the scientific literature devoted to the study of management teams, their functionality and further effectiveness in 
their work. Some papers have noted that the psychological aspect is also important. Work effectively the management team works effectively when its members are friendly to one another. There must be camaraderie. The difference between mediocrity and talent lies in the feeling that members of the management team have in each other.

The effectiveness of management teams is also based on the fact that in the course of its functioning, "group thinking" is opposed to "team thinking". Scientists have argued that group thinking is not productive, because the team has one thought, and team thinking, on the contrary, helps to creatively solve problems.

Setting objectives of the article. The purpose is to substantiate the productive characteristic of "team thinking" in management teams.

Results. The transition from an industrial to a post-industrial and, finally, information society has led to a change in the main resource that information has become. In the context of continuous improvement of mechanisms of work with information, the orientation to the knowledge of only one person significantly increases the risk of economic activity. And the high level of knowledge and professional activity of the specialists encourage their desire to participate in the management.

As a result, most organizations make management at various levels responsible for a broader range of tasks then anyone they can handle personally. For them to bear this responsibility, one or another form of collective management is created, based on the redistribution of responsibility.

In this sense, team building is at the forefront of managerial innovations that are appropriate to implement at enterprises of the maritime economy. You should agree with Y. O. Verstau it is true that teamwork is a powerful tool for achieving synergy and contributing to maximum productivity in the process of solving common tasks. This effect is reflected at all stages of the team decision-making process and provides not only a choice of the best of them but also a creative, non-standard approach to the case [1].

A team should be understood as a social group in which informal relationships between its members may be more important than formal 
ones, and the actual role and influence of the individual does not match his or her official status and weight [2].

The command principle is based on the thesis that operational tasks can be performed by individual employees, but to enhance the work of the organization, employees are grouped into permanent small groups. In these groups, the efforts of individual individuals complement each other. In such cases, when the efforts of the employees are interdependent, they act as a special team, which should solve professional tasks and achieve a high level of interaction [3, p. 85].

For psychology, teamwork involves the formation of a special way of interaction of people in an organized group, which allows them to effectively realize their energy, intellectual and creative potential according to the strategic goals of the organization.

Based on the chosen mission and purpose of the team, the appropriate type of joint activity is determined, namely: jointly-individual, jointly-consistent, jointly-cooperative or jointly-creative. In turn, the type of joint activity is the basis for choosing the formal structure of the team with its leadership, role composition, the list of knowledge, skills, and competencies that must have team members, task deadlines, and degree of control over execution by management, etc. [4].

Now we can talk about the formation of a separate direction in management - team management, which is related to the following trends in the field of organizational development and high-performance management.

1. Modern organizations are characterized by pronounced tendencies to structural complexity, which requires the introduction of more effective organizational forms and methods of collective management, which would minimize the time of decision making and at the same time improve its quality. The situation can be solved by creating a well-formed management team.

2. Almost all organizations that are successfully developing and are characterized by high competitiveness, work first and foremost. In this sense, they create innovative units that are characterized by high mobility of organizational structures, depending on changing tasks. Their successful operation is based, in particular, on the creation of 
an atmosphere of creative search, as well as a team of like-minded people who take responsibility for the prospects of development of the organization together with the administration, which is essentially a manifestation of the team approach in innovative management.

3. Increasing the productivity of managerial work depends on the realization that a manager of any rank is associated with the creation of a collective product of labor. In this sense, the introduction of a "spirit of command" is of great importance as a motivating factor for improving the productivity of the organization as a whole.

4. Modern executives view the culture of the organization as a powerful strategic tool that allows you to orient all units and individual professionals to common goals, mobilize employee initiative and facilitate productive communication between them. In this sense, the effect of the team, its public recognition comes after long work together and real successes [5].

There is no universally recognized unified interpretation of the term management team, however, logically, it is a group of leaders of different levels, linked informally by the unity of understanding of the perspective of the organization and methods of its achievement, pursuing a single coherent policy with a view to achieving the goals set in the conditions resource constraints.

The expediency of using teams as a form of collective management is indisputable in cases where management at different levels is forced to take responsibility for a wider range of tasks than one that can be dealt with personally. And within the team, there can be a constant redistribution of responsibility with a change in the parity of authority. On the other hand, to ensure that this redistribution does not turn into a kind of "transfer of the chip", it is necessary to ensure a high level of professionalism of each member of the management team.

The psychological aspect is also important. After all, as L. Jakocka rightly remarked, to work as an effective management team, its members must treat each other humanly, love each other. There must be camaraderie. The difference between mediocrity and talent lies in the feeling that members of the management team have in each other [6].

The effectiveness of management teams is also based on the fact that in the course of its functioning, "group thinking" is opposed to 
"team thinking". And if group thinking is usually based on a predilection for the choice of one thought (linear approach), then "command" aims at identifying different, even conflicting, opinions (nonlinear approach, which justifies the multiplicity of decisions). When "group thinking" syndrome is triggered, the total effect of team members' intellectual efforts is lower than that of individual team members. In the case of "team thinking", people are free to express their thoughts and create a synergy effect without feeling pressure from their leaders or colleagues [7].

On the other hand, it should be remembered that the managerial staffing capacity is always limited when forming a management team. After all, in the context of teamwork, there is a phenomenon of "lack of managerial stars" when a specialist who was successful in one organization, when moving to a new organization (or a new team) will not be as successful, because it has other organizational conditions of activity. Thus, the manager must be satisfied with the average level of professionalism of the subordinates and create the necessary conditions for their professional growth in the process of further activity [8].

At B. Takman's suggestion, the path most teams take to achieve high performance is often divided into 5 stages: formation, shock, normalization, embodiment, dissolution [9, p. 388].

Other scholars, such as K. S. Kalinets, point out that team formation is a dynamic process; moreover, some teams are in a state of permanent change and never achieve stability. However, even in this case, there is a general pattern for the evolution of most teams: formation, shock, normalization, task completion and dissolution [10].

At the enterprises of the maritime complex, teams can be formed, both in the course of the implementation of individual innovation projects and in the context of the current activity of each enterprise to create new products or services, search for creative ideas, ways to increase sales, etc. [11, p.138]. Also, management teams can be intraand inter-sectoral.

To quantify the effectiveness of the management team, it is possible to use the Steiner formula [12, p. 84]: 


$$
\mathrm{AP}=\mathrm{PP}+\mathrm{S}-\mathrm{T}
$$

where: AP is the actual performance;

$\mathrm{PP}$ - potential productivity;

$\mathrm{S}$ - synergy;

$\mathrm{T}-$ threats of activity.

According to the formula (1) (actual team performance is determined by three factors: potential productivity, synergism, and threats.

Potential performance depends on the requirements and resources available, the professional competencies of the manager and team members, and the tasks that the team needs to accomplish. Synergy reflects the options that can be improved by teamwork compared to individuals $(1+1>2)$. And threats are mistakes in team interaction that can arise in the event of a lack of coordination or motivation $(1+1<2)$.

In terms of specific approaches to team management, Agile, Scrum, Kanban, and APF have gained the most popular in recent years (Table 1).

It should also be emphasized that working in a management team implies that each member of the group identifies himself or herself as a specialist belonging to a particular social group. That is why employees are often sorely distracted from their workplace, even when there is another, more financially attractive offer [14, p. 25].

A competitive team should be understood as the highest level of its development. The need to form such teams is due to the strong competition, which due to some socio-economic and socio-psychological reasons is observed today in all types of organizations. The essential characteristics of a competitive team are the following:

- each team member has a competitive personality;

- each team member perceives competition as an impetus for their self-improvement;

- rapid adaptation to changes in the world;

- the indifference of all members of the team - like-minded in their business;

- rate on continuous professional improvement; 
- $\quad$ support for high creativity, including the constant generation of new, original ideas [15].

Table 1

Characteristics of some approaches to team management

\begin{tabular}{|l|l|l|}
\hline Approaches & \multicolumn{1}{|c|}{ Characteristic } & $\begin{array}{l}\text { Possibility of application in } \\
\text { the maritime complex }\end{array}$ \\
\hline Agile & $\begin{array}{l}\text { Principles: Individuals and interactions outweigh } \\
\text { processes and tools, customer engagement, and } \\
\text { response to change throughout the plan. The project } \\
\text { team runs iterative cycles, with a mandatory } \\
\text { evacuation of the results at the end of each. } \\
\text { Depending on the results of these assessments, the } \\
\text { deadlines may be modified to better meet the client's } \\
\text { needs. Continuous collaboration is a key aspect, both } \\
\text { within the project team and among all stakeholders. }\end{array}$ & $\begin{array}{l}\text { Sea fraight and passenger } \\
\text { tourism. }\end{array}$ \\
\hline Scrum & $\begin{array}{l}\text { There is a small team led by a Scrum wizard whose } \\
\text { main job is to remove all obstacles to the work of the } \\
\text { team, increasing its effectiveness. The team runs } \\
\text { short cycles called "sprints". }\end{array}$ & $\begin{array}{l}\text { Projects in tourism and } \\
\text { recreation. }\end{array}$ \\
\hline Kanban & $\begin{array}{l}\text { Project teams create visual representations of their } \\
\text { tasks (using notes on the boards or through software } \\
\text { applications) and move them through specific stages } \\
\text { defined in advance to see the progress of the whole } \\
\text { and the individual elements, as well as each } \\
\text { participant's tasks and possible problems. }\end{array}$ & $\begin{array}{l}\text { Any team activity at all } \\
\text { levels of management. }\end{array}$ \\
\hline APF & $\begin{array}{l}\text { The project undergoes a series of iterations, and at } \\
\text { the end of each team evaluates the preliminary } \\
\text { results to increase efficiency and translate best } \\
\text { practices. Stakeholders can also modify the project } \\
\text { framework at the beginning of each stage to improve } \\
\text { the result. }\end{array}$ & $\begin{array}{l}\text { Realization of projects in } \\
\text { shipbuilding. }\end{array}$ \\
\hline
\end{tabular}

Source: Compiled by the authors [13].

Therefore, the management team must be formed in such a way that its members simultaneously achieve financial well-being and social status and at the same time perform their functions qualitatively. The key to such effective team activity is the distribution of role functions. All team roles are divided into target and supportive. Team members performing targeted roles direct their energy to solve problems facing the team, and team members performing supporting roles help to support and enhance team members' activities. 
For the members of the team implementing the target, roles are characterized by the following qualities: initiative, search for alternatives, exchange of views, information processing, control over implementation, summarizing. The member of the team performing the target role carries a huge functional load, so the execution of several target roles by one person at the same time is not desirable. In turn, team members who play supportive roles are friendly, responsive, positively appraise others, create harmony, eliminate conflicts, reduce tensions, and are ready to compromise.

Like the roles, the professional knowledge of each manager cannot be the same but depending on his place in the management team, as well as in the hierarchy of the organization. In these circumstances, the specialization of each manager, differentiation of types of management work, coordination of joint and functional actions are the guarantee of effective functioning of the management team.

Besides, for maximum efficiency, the management team should be flexible and dynamic. Therefore, not only emotional integration and achievement of results within the framework of management tasks but also the ability to respond quickly to external and internal changes becomes important for its participants. In this context, it is important to create an appropriate information environment and technological support, both within individual teams and within the enterprise or organization as a whole. After all, quite a few software products have emerged in recent years to assist team management work. In particular, Google services simplify teamwork, Proficonf continually improves team communication processes, and makes it easier to control individual project tasks with the Trello application.

Thus, in Ukraine, there is both a request from the enterprises of the maritime complex and the appropriate organizational capabilities for the effective functioning of management teams. The creation of teams should be carried out using mechanisms that cover both the interests of enterprises, as well as personal aspects and the internal motivation of managers. Among the factors that impede the implementation of command forms of management can be highlighted by their lack of flexibility in the need for urgent decision-making, the need for tangible costs to create a team and resistance from individual managers who are accustomed to working independently. 
Conclusions and recommendations. The problem of team thinking is a complex aspect of management, both from a psychological point of view and from a managerial point of view. The concepts are similar to group thinking.

On the one hand, there are advantages: creative ideas, rapid problem solving and a close-knit team. However, each theory has its drawbacks.

Each team has staff that is in one way or another contacted.

Some workers are very good at their individual qualities but find it difficult to reach the group. Regardless of the position occupied by an employee, it can be effective in a separate job. On the one hand, we have a good employee who does not want to be fired, and on the other, a threat to team thinking and teamwork. This is the first problem.

The second is that, even in like-minded people, there can be differences in a friendly team on a particular issue. At this point, a competent approach from a psychological point of view is needed. A creative approach to solving this problem will not help here because there will be a clash of interests within the team. And the solutions to this problem already take a time that could be spent on another issue. This will cause a slowdown in the work of the team, which will not lead to a positive result in solving the initial task. The article presented a formula for identifying the necessary primary information about the effectiveness of the team.

Foreign scientists have identified several approaches to team management, the article considered four approaches:

Agile is continuous collaboration with the client

Scrum - remove all obstacles to the work of teams

Kanban is a visual representation of tasks

APF - Stakeholders can amend.

Based on the analysis of these approaches, we have identified the possibilities of their application in the maritime complex.

In conclusion, I can say that the key factor is to achieve a certain social status, both for the company as a whole, and personally for each employee, and certainly the financial profit of the organization in the most effective functioning of teams. 


\section{Bibliography}

1. Верста Ю. О. Психологічні особливості процесу прийняття командних рішень. Вiсник Львів. ун-ту. Серія : Філософські науки. 2006. Вип. 9. С. 280-287.

2. Геллерт М., Новак К. Все о командообразовании. Руководство для тренеров. Москва : Издательство «Вершина», 2006. 352 с.

3. Ньюстром Дж. В., Дэвис К. Организационное поведение. Санкт-Петербург : Издательство Питер-Юг, 2000. 448 с.

4. Базаров Т. Ю. Управленческие команды и их формирование. URL: http://www.cpt21. ru/pub/teachers/ 17/2312031072203368.doc (дата звернення: 20.07.2019)

5. Зинкевич-Евстигнеева Т. Д., Фролов Д. Ф., Грабенко Т. М. Теория и практика командообразования. Современная технология создания команд / Под ред. Т. Д. ЗинкевичЕвстигнеевой. Санкт-Петербург : Речь, 2004. 304 с.

6. Якокка Л. Карьера менеджера. Москва : Попурри, 2002. 416 с.

7. Хитра О. В. Синергетичні аспекти створення та функціонування управлінської команди URL: http://elar.khnu.km.ua/jspui/bitstream/123456789/5001/1/Khytra_visnyk_ MGU_v18_2016.pdf (дата звернення: 20.07.2019)

8. Борщ В. І., Бевзюк Д. В. Управлінська команда: сучасні технології формування. Ринкова економіка: сучасна теорія і практика управління. 2018. Том 17. Вип. 1 (38). URL: http://rinek.onu.edu.ua/article/view/135312/136385 (дата звернення: 20.07.2019)

9. Tuckman, Bruce W. Developmental sequence in small groups. Psychological Bulletin. Vol 63 (6) Jun. 1965, Pp. 384-399.

10. Калинець К. С. Сутність та особливості формування управлінської команди. URL: http://me.fem.sumdu.edu.ua/docs/d097.pdf (дата звернення: 20.07.2019)

11. Оленіч А. В., Шацька 3. Я. Формування і розвиток проектної команди в сучасних умовах. Актуальні проблеми економіки. 2012. № 10. С.136-142.

12. Томпсон Л. Создание команды. Москва : Вершина, 2006. 544 с.

13. Марцінковська О. Б. Сучасні підходи до управління командами в контексті реалізації проекту. Регіональні аспекти розвитку продуктивних сил України. 2016. Вип. 21. С. 102-108.

14. Помаз О. М, Шульженко І. В. Особливості створення ефективної управлінської команди в сучасних умовах. Науковий вісник Полтавського університету економіки і торгівлі. Серія : Економічні науки. 2016. № 1. С. 23-28.

15. Любчук О. К. Функціонування ефективної управлінської команди як форми вдосконалення взаємодії влади з громадськістю. URL: http://www.investplan.com.ua/ pdf/14_2013/26.pdf (дата звернення: 29.06.2019)

Стаття надійшла 02.10.2019 року

\section{Горбаченко С. А.,}

кандидат экономических наук, доцент кафедры менеджмента и инноваций

Одесского национального университета им. И.И. Мечникова

Французский бульвар, 24/26, Одесса, 65058, Украина, e-mail: stas_gorbachenko@ukr.net 
Market economv: modern management theorv and practice. Vol. 18. Issue 3 (43) ISSN 2413-9998

\author{
Харламова В. В., \\ студентка второго курса магистратуры \\ специальности внешнеэкономической деятельности \\ Одесского национального университета им. И. И. Мечникова \\ Французский бульвар, 24/26, Одесса, 65058, Украина, \\ e-mail: kharlamova7.16@gmail.com
}

\title{
УПРАВЛЕНЧЕСКИЕ КОМАНДЫ
}

Исследуются особенности создания управленческих команд в Украине на современном этапе информационного общества для решения поставленных задач. С развитием технологий растет и ответственность у людей за их работу, следовательно, для упрощения и производительности работы коллектива начали в больших организациях появляться группы людей, которые распределяют между собой обязанности. Метод решения проблем с помощью «командного мышления» значительно улучшает работу организации, такие показатели, как: количество идей, креативный подход к решению проблем и сплочения коллектива. Проанализированы актуальные проблемы формирования отдельного направления в управлении и предложены пути эффективного функционирования управленческих команд. В статье рассмотрено современный опыт подходов к менеджменту команд.

Ключевые слова: управленческие команды; менеджмент; управление персоналом; профессиональная активность специалистов; формирование команд; управленческие инновации; морехозяйственный комплекс; командное мышление.

\author{
Горбаченко С. А., \\ кандидат економічних наук, \\ доцент кафедри менеджменту та інновацій \\ Одеського національного університету ім. І. І. Мечникова \\ Французький бульвар, 24/26, Одеса, 65058, Україна, \\ e-mail: stas_gorbachenko@ukr.net \\ Харламова В. В., \\ студентка другого курсу магістратури \\ спеціальності зовнішньоекономічної діяльності \\ Одеського національного університету ім. І. І. Мечникова \\ Французький бульвар, 24/26, Одеса, 65058, Україна, \\ e-mail: kharlamova7.16@gmail.com
}

\section{УПРАВЛІНСЬКІ КОМАНДИ}

Досліджуються особливості створення управлінських команд в Україні на сучасному етапі інформаційного суспільства для вирішення поставлених завдань. 
3 розвитком технологій зростає і відповідальність у людей за їх роботу, отже, для спрощення і продуктивності роботи колективу почали у великих організаціях з'являтися групи людей, які розподіляють між собою обов'язки. Метод розв'язання проблем за допомогою «командного мислення» значно покращує роботу організації, такі показники, як: кількість ідей, креативний підхід до розв'язання проблем і згуртування колективу. Проаналізовано актуальні проблеми формування окремого напрямку в управлінні та запропоновано шляхи ефективного функціонування управлінських команд. У статті розглянуто сучасний досвід підходів до менеджменту команд.

Ключові слова: управлінські команди; менеджмент; управління персоналом; професійна активність фахівців; формування команд; управлінські інновації; морегосподарський комплекс командне мислення.

\section{References}

1. Versta, Yu. O. (2006). Psykholohichni osoblyvosti protsesu pryiniattia komandnykh rishen [Psychological features of the team decision-making process.]. Visnyk Lviv. un-tu. Seriia : Filosofski nauky. - Bulletin of Lviv University. Philosophy sciences, Issue 9, Pp. 280-287. [in Russian].

2. Gellert, M. \& Novak, K. (2006). Vse o komandoobrazovanii. Rukovodstvo dlia trenerov [Everything about team building. Guide for trainers.]. Moskva : Izdatelstvo "Vershyna". [in Russian].

3. Niustrom, D. V. \& Devis, K. (2000). Organizatsionnoe povedenie [Organizational Behavior]. Sankt-Peterburg : Izdatelstvo Piter-Yug. [in Russian].

4. Bazarov, T. Y. (2016). Upravlencheskie komandy i ikh formirovanie [Management teams and their formation.] Retrieved from: http://www.cpt21.ru/pub/teachers/ 17/2312031072203368.doc. [in Russian].

5. Zinkevich-Evstihneeva, T. D., Frolov D. F. \& Grabenko, T. M. (2004). Teoriia i praktika komandoobrazovaniia. Sovremennaia tekhnologiia sozdaniia komand [The theory and practice of team-building. Modern technology of command creation]. Sankt-Peterburg : Rech. [in Russian].

6. Yakokka, L. (2002). Karera menedzhera [Manager's career]. Moskva : Izdatelstvo «Popurri». [in Russian].

7. Khytra, O. V. (2016). Synerhetychni aspekty stvorennia ta funktsionuvannia upravlinskoi komandy [Synergistic aspects of the management team creation and functioning]. Retrieved from: http://elar.khnu.km.ua/jspui/ bitstream/123456789/5001/1/Khytra_visnyk_MGU_v18_2016.pdf [in Ukrainian].

8. Borshch, V. I. \& Bevziuk, D. V. (2018). Upravlinska komanda: suchasni tekhnolohii formuvannia [Management team: modern technologies of team builing]. Rynkova ekonomika: suchasna teoriia i praktyka upravlinnia. - Market economy: modern management theory and practice. Retrieved from: http://rinek.onu.edu.ua/article/ view/135312/136385 [in Ukrainian].

9. Tuckman, Bruce W. (1965). Developmental sequence in small groups. Psychological Bulletin, Vol. 63 (6), Pp. 384-399.

10. Kalynets, K. S. (2015). Sutnist ta osoblyvosti formuvannia upravlinskoi komandy 
[The essence and peculiarities of forming the management team]. Retrieved from: http://me.fem.sumdu.edu.ua/docs/d097.pdf [in Ukrainian].

11. Olenich, A. V. \& Shatska, Z. Ya. (2012). Formuvannia i rozvytok proektnoi komandy $\mathrm{v}$ suchasnykh umovakh [Formation and development of the project team in modern conditions]. Aktualni problemy ekonomiky. - Current problems of economy, № 10, Pp. 136-142. [in Ukrainian].

12. Tompson, L. (2006). Sozdanie komandy [Team building]. Moskva Izdatelstvo : "Vershyna». [in Russian].

13. Martsinkovska, O. B. (2016). Suchasni pidkhody do upravlinnia komandamy $\mathrm{v}$ konteksti realizatsii proektu [Modern approaches to team management in the context of project implementation]. Rehionalni aspekty rozvytku produktyvnykh syl Ukrainy. - Regional aspects of development of productive resources, Vol. 21, Pp. 102-108. [in Ukrainian].

14. Pomaz, O. M \& Shulzhenko, I. V. (2016). Osoblyvosti stvorennia efektyvnoi upravlinskoi komandy $\mathrm{v}$ suchasnykh umovakh [Features of creation of effective management team]. Naukovyi visnyk Poltavskoho universytetu ekonomiky i torhivli. Seriia : Ekonomichni nauky. - Scientific herald Of Poltava university of economics and trade, 1, Pp. 23-28. [in Ukrainian].

15. Lyubchuk, O. K. (2013). Funktsionuvannia efektyvnoi upravlinskoi komandy yak formy vdoskonalennia vzaiemodii vlady z hromadskistiu [Functioning of an effective management team as a form of improvement of interaction between the authorities and the public]. Retrieved from: http://www.investplan.com.ua/pdf/14_2013/26.pdf [in Ukrainian]. 